\title{
EU a Austrálie ve Světové obchodní organizaci
}

\author{
Erika Novotná
}

Vedoucí práce: prof. Ing. Eva Cihelková, CSc.

\section{Úvod}

Evropská unie (dále také „EU“"nebo „Unie“) a Austrálie představují i přes značnou geografickou vzdálenost přirozené politické, ekonomické i sociální partnery. Jednak jsou jejich politické systémy postaveny na stejných hodnotách a principech fungování a jednak jsou společně členy v řadě mezinárodních organizací (např. OSN nebo WTO). Významný je také vliv kulturních a historických vazeb na členské státy EU. ${ }^{1}$ Vzájemná spolupráce partnerů se uskutečňuje převážně na bilaterální úrovni. V silné a efektivní Světové obchodní organizaci (dále jen „WTO“) vidí však oba subjekty klíčovou roli pro zajištění př́ínosů procesů globalizace a uvědomují si význam vzájemné spolupráce v rámci této organizace. ${ }^{2}$ Na půdě WTO dominují v současnosti vzájemným vztahům EU a Austrálie především odlišné ambice $\mathrm{v}$ otázce reformy obchodu zemědělskými produkty a brání tak jejich těsnějšímu partnerství v rámci této organizace. ${ }^{3}$ Austrálie zaujímá zásadně negativní postoj proti jakýmkoli ochranářským snahám EU. Proto se k pokusům EU zahrnout do jednání o zemědělství jiné neobchodní otázky staví podezř́ivavě a podobné snahy vnímá jako skrytý projev protekcionismu (jedná se např. o otázky rozvoje venkova, ochrany životního prostředí, bezpečnosti potravin nebo také zeměpisných označení). ${ }^{4}$

Záměrem této práce je vypovědět o aktuálních otázkách vzájemných vztahů EU a Austrálie, a to s ohledem na působení obou subjektů ve WTO. Část první se věnuje vzájemným vztahům partnerů z obecnějšího hlediska, uvedeny jsou nezbytné souvislosti a širší kontext obchodní spolupráce obou subjektů. Náplní dalších dvou částí jsou pak nejprve společné zájmy a následně sporné oblasti vzájemných vztahů EU a Austrálie, vždy s ohledem na působení partnerů ve WTO. Cílem práce nebylo podat analýzu jakkoli komplexní nebo vyčerpávající, ale zaměřit se na působení obou subjektů v rámci multilaterálního obchodního systému v současné době. S ohledem na rozsah práce jsou zcela opominuty historické souvislosti vzájemné spolupráce.

1 Cihelková, E.: Vnějši ekonomické vztahy Evropské unie. 1. vyd., Praha, C. H. Beck, 2003, s. 247.

2 Cihelková, cit. 1, s. 247.

3 Kenyon, D. and Kunkel, J.: Australia and the European Union in the World Trade Organisation: partners or adversaries? Australian Journal of International Affairs, březen 2005, roč. 59, č. 1, s. 55.

4 Kunkel, J.: Australian trade policy in an age of globalisation. Australian Journal of International Affairs, 2002, roč. 56 , č. 2 , s. 240. 


\section{Specifika vzájemných vztahů: asymetrie a rezidualismus}

Povaha obchodních vztahů EU a Austrálie je odrazem vlivu jednak širších strukturálních faktorü ${ }^{5}$ a jednak určité asymetrie ve vzájemných vztazích. EU představuje jeden z největších obchodních celků na světě a zahrnuje 6 z 10 zemí s největšími objemy exportů a importů z hlediska celosvětového obchodu zbožím (Německo, Velkou Británii, Francii, Itálii, Nizozemsko a Belgii). Nebereme-li v úvahu vnitrounijní obchodní výměnu, je EU rovněž největším světovým exportérem zboží a druhým největším importérem. Austrálie se z hlediska celkového objemu obchodu pohybuje mezi 21. (import) a 27. prŕíčkou (export) na světě. Po odečtení vnitrounijního obchodu se pozice země vylepší zhruba o 8 příček. Již od 80. let je EU největším obchodním partnerem Austrálie. ${ }^{7} \mathrm{~V}$ opačné relaci se Austrálie vyskytuje na 12. prričce seznamu zemí, kam směřují exporty EU a 27. př́ičce, pokud jde o australské importy na území Unie. ${ }^{8}$

Naznačená asymetrie ve vzájemných vztazích partnerů má své přímé důsledky nejen v obchodních vztazích na bilaterální úrovni, ale projevuje se také v pozicích, které tyto subjekty zaujímají v mezinárodních organizacích. EU významně ovlivňuje podobu multilaterálního obchodního systému, je jedním z největších ekonomických celků na světě a díky tomu rovněž jedním z klíčových hráčů ve WTO. V rámci společné obchodní politiky jedná Evropská komise za všech 25 členských států. Jako taková je tak EU hybnou silou v současnosti probíhajícím kole multilaterálních obchodních jednání WTO, v Rozvojové agendě z Dauhá. ${ }^{9}$ Především díky velikosti vnitřního trhu, preferenčních vztazích a rozvojové pomoci uplatňuje Unie velký vliv na mnoha místech světa, např. v Africe, na Středním východě nebo východní Evropě. Ve srovnání s EU má Austrálie mnohem menší schopnost ovlivňovat mnohostranná obchodní jednání. Tam, kde EU vytváří pravidla procesu globalizace a obchodního systému jako celku, představuje Austrálie středně významnou obchodní sílu s mnohem omezenější vyjednávací pozicí. ${ }^{10}$ Při snaze uplatnit vliv na podobu agendy WTO, se Austrálie musí spoléhat na koalice, zejména na Cairnskou skupinu (Cairns Group) ${ }^{11}$ vytvořenou za účelem prosazování tržně orientovaných zemědělských politik. Pozice Austrálie v rámci WTO je tak podmíněná schopností budovat širší podporu pro prosazení svých zájmů např́íč celým spektrem členských států. Mimo Cairnskou skupinu toto předpokládá navazování užších pracovních partnerství, často na ad hoc bázi, s vlivnějšími členy WTO jako USA, Japonskem i EU.

Vzájemné vztahy partnerů jsou poznamenány také určitým rezidualismem. Tato tendence vychází z hierarchie vnějších vztahů uplatňované Bruselem a Canberrou. V př́ípadě

5 Z teritoriálního hlediska představuje Austrálie subjekt velkého ekonomického rozměru (7 682 tisíc km²), vyznačuje se však značně omezeným vnitřním trhem (20,4 mil. obyvatel v roce 2005). Pro porovnání v EU dnes žije 457 mil. obyvatel na necelých čtyřech milionech $\mathrm{km}^{2}$. Přes pokročilou diversifikaci australského hospodářství jsou zemědělské produkty a suroviny nejdůležitějšími exportními položkami.

6 International Trade Statistics 2006. http://www.wto.org/english/res_e/statis_e/its2006_e/its06_toc_pdf_links_e. htm.

7 V roce 2005 dosáhl objem vzájemného obchodu 33415 mil. EUR, což představovalo 18,2\% veškerého zahraničního obchodu Austrálie. Obchod s USA dosáhl 11 \%, s ASEAN 15,7 \%, s Japonskem 15,6 \% a Čínou

8 Australia. Statistics. http://trade.ec.europa.eu/doclib/docs/2006/september/tradoc_113346.pdf.

9 The EU and the WTO. http://ec.europa.eu/trade/issues/newround/index_en.htm.

10 Kunkel, cit. 5, s. 240.

11 Cairnská skupina představuje různorodou koalici 18 zemí exportujících zemědělské produkty. Mezi členy se řadí jak vyspělé tak rozvojové země Latinské Ameriky, Afriky a asijsko-pacifického regionu. Cílem skupiny je liberalizace obchodu zemědělskými produkty. Austrálie je permanentně předsedající zemí skupiny a uplatňuje tak významný vliv na ostatní členy. Členové jednotlivě: Austrálie, Argentina, Bolívie, Brazílie, Kanada, Čile, Kolumbie, Kostarika, Guatemala, Indonésie, Malajsie, Nový Zéland, Paraguay, Pákistán, Filipíny, Jižní Afrika, Thajsko, Uruguay. (http://www.cairnsgroup.org/). 
EU jsou to vztahy s globálními a významnými regionálními mocnostmi jako USA, Ruskou federací, Japonskem, Č́nou a Indií, které dominují. V zahraničně obchodní politice Austrálie se zase ve středu zájmu, jakkoli překvapivě s ohledem na význam EU jako obchodního partnera, nacházejí primárně regiony východní Asie, Pacifiku a USA. ${ }^{12}$

\section{Oblasti společných zájmů}

Vznik WTO jako klíčový výsledek Uruguayského kola GATT potvrdil centrální roli mnohostranného obchodního systému v období globalizace. Ustavení prř́snějších pravidel donucovacího mechanismu spolu se systémem urovnávání sporů v rámci WTO představoval významný krok v tomto kontextu a byl silně podporován jak EU tak Austrálií. ${ }^{13}$

Přes rozdílné priority hráli také oba partneři významné role při vyjednání vyváženého mandátu na setkání WTO v Dauhá v roce 2001 a následně podporovali jeho ambiciózní interpretaci směrem k prosazení dalšího omezení tarifních a netarifních překážek obchodu průmyslovým zbožím. EU i Austrálie usilovaly rovněž o pokrok v liberalizaci služeb s důrazem na asijský region.

Pozice partnerů se shodují také v otázkách jako je podpora domácí regulované liberalizace $\mathrm{v}$ rozvojových zemích, zachování volného trhu pro e-commerce nebo usnadňování volného pohybu osob za účelem dodávky některých druhů služeb. ${ }^{14}$

Společné zájmy jsou rovněž patrné z jednání o klasifikaci a zdokonalení pravidel WTO. Oba partneři prosazují pravidla WTO, která jsou transparentní, předvídatelná a efektivní.

Navzdory rozdílům $\mathrm{v}$ některých konkrétních př́ípadech, EU a Austrálie sdílejí společný zájem na zabránění zneužívání ochranných nástrojů obchodní politiky včetně anti-dumpingových opatření, subvencí nebo vyrovnávacích cel. Oba partneři jsou také zajedno v otázce zlepšování dosavadních pravidel v oblastech technických bariér obchodu a regionálních obchodních dohod. ${ }^{15}$

Při setkání WTO v Cancúnu v září 2003 se ukázalo zřejmým, nakolik je další pokrok v jednáních závislý na lepší integraci rozvojových zemí do světového obchodního systému. ${ }^{16}$ Nalezení správné rovnováhy ve WTO mezi liberalizací obchodu, vytvářením nových pravidel a citlivostí k zájmům rozvojových zemí tak představuje další významný společný zájem obou partnerů.

\section{Sporné oblasti vzájemných vztahů}

Obchodní vztahy EU a Austrálie jsou dnes mnohem rozvinutější a obsažnější než kdykoli v minulosti. Stejně tak narůstá počet oblastí společných zájmů partnerů při mnohostranných obchodních jednáních. Přesto zůstávají vzájemné vztahy na půdě WTO determinovány rozpory nad otázkou zemědělství a je tak nezbytné konstatovat, že oblast zemědělství nadále zůstává určujícím prvkem těsnějších vztahů obou partnerů

12 Kunkel, cit. 5, s. 239; Australia. The Trade policy. http://ec.europa.eu/trade/issues/bilateral/countries/australia/tp. htm.

13 Kunkel, cit. 5, s. 240.

14 Kenyon, cit. 4, s. 56.

15 World Trade Organisation (WTO) Doha Round Negotiations. http://www.dfat.gov.au/trade/negotiations/index. html.

16 Special Report: The WTO under fire - The Doha round; The Doha round. Economist, 2003, roč. 368, č. 8342, s. 30. 
$\mathrm{v}$ rámci této organizace. $\mathrm{S}$ ohledem na roli zemědělské produkce jako klíčové exportní komodity Austrálie a na současný vývoj v jednáních WTO by stěžejní role této otázky ve vzájemných vztazích neměla být podceňována. ${ }^{17}$ Reforma multilaterálního obchodního systému směrem k efektivní a volné soutěži v oblasti zemědělství představuje dlouhodobý zájem australské obchodní politiky. Austrálie stojí v popředí snah reformovat ochranářství a subvence $\mathrm{v}$ sektoru zemědělství, domáhá se zlepšení přístupu na trh zemědělskou produkcí, omezení dotací farmářưm narušujících obchod a restrikcí vývozních subvencí. Tomu odpovídá skutečnost, že Austrálie vykazuje druhou nejnižší míru zemědělské podpory a ochrany mezi členskými státy OECD. ${ }^{18}$ EU jako ekonomický subjekt s výrazně vyšší celkovou úrovní zemědělských subvencí se tak nevyhnutelně ocitá ve středu pozornosti australské agendy na liberalizaci obchodu zemědělskými produkty.

Proti těmto liberalizačním cílům zahraničně-obchodní politiky Austrálie stojí snaha EU o vyvážený přistup $\mathrm{k}$ zemědělství založený na argumentu, že se jedná o činnost zvláštního druhu. EU navrhuje spíše pomalejší tempo reformování této oblasti na multilaterální úrovni a spojuje omezování podpor zemědělcům $\mathrm{s}$ pokrokem $\mathrm{v}$ jednáních o neobchodních zájmech. Tržně orientovaná agenda Austrálie je proto často označována až za extremistickou. Pozice EU v jednáních o zemědělství jsou důsledkem jednak reforem v rámci Agendy 2000 a jednak reformních opatření dohodnutých v červnu 2003. Přestože se jedná o značný pokrok oproti stavu na počátku 90. let, bude zapotřebí ještě mnoha opatření než se nepř́źznivé účinky Společné zemědělské politiky EU (dále také „SZP“) na světový obchod podaří eliminovat. Navzdory tomu lze konstatovat, že zejména díky tlaku na snižování rozpočtu, rozšiřování EU, jakož i díky externím tlakům především v rámci mnohostranných jednacích kol je SZP na správné cestě pro uskutečnění zásadních změn. Budoucí vývoj SZP se tak pravděpodobně bude ubírat směrem k nižším intervenčním cenám a dotacím odpoutaným od objemu výroby a přizpůsobeným podpoře specifických cílů v oblasti ochrany životního prostředí a regionálního rozvoje. Celý reformní proces však patrně nebude postupovat dostatečně rychle na to, aby uspokojil zájmy Austrálie, zbytku Cairnské skupiny a ostatních vyspělých i rozvojových zemích, pro které je otázka volného obchodu zemědělskými produkty důležitou. ${ }^{19}$

Př́ikladem jiných, se sektorem zemědělství však souvisejících oblastí, kde existují rozpory v pozicích partnerů, je např. otázka zeměpisných označení. EU naléhá na rožšřření jejich mnohostranné ochrany, oproti tomu stojí Austrálie v popředí opozice proti podobným snahám. ${ }^{20}$ EU rovněž požaduje širší mandát WTO v oblasti životního prostředí. Austrálie však spolu ostatními významnými exportéry zemědělských produktů považuje podobné snahy za ohrožující nebo alespoň zpomalující reformu sektoru zemědělství a omezující př́stup na trhy zemědělských produktů. ${ }^{21}$

Přestože se v posledních letech objevily právě výše zmíněné a podobné otázky, středem zájmu jednání o Rozvojové agendě z Dauhá zůstává nadále primárně otázka přístupu na trh zemědělských produktů a omezování podpor narušujících volný obchod $\mathrm{v}$ tomto sektoru.

17 Kenyon, cit. 4, s. 56.

18 Agricultural Policies in OECD Countries: At a Glance. 2006 Edition. OECD Publications. Paris 2006, s. 35.

19 Der Ärger über das Aussetzen der Doha-Runde wächst. Frankfurter Allgemeine Zeitung, 23.09.2006, s. 14.

20 Geographical Indications. http://www.dfat.gov.au/ip/geographical_indications.html.

21 Kenyon, cit. 4, s. 62. 


\section{Závěr}

Pokročilé stadium ekonomické integrace a potřeba zachovat si konkurenceschopnost v globálním měřítku vytvářejí tlak na stále otevřenější a liberálnější obchodní politiku EU. V rámci většiny obchodní agendy tak existuje prostor pro těsnější partnerství. Oblast zemědělství však zůstává významnou výjimkou jinak otevřené a liberální obchodní politiky Unie. EU i Austrálie spoléhají na roli WTO při zajiš ování globálních obchodních př́ležitostí a udržování efektivních obchodních pravidel, které zajiš ují otevřené trhy a účinný systém urovnávání sporů. Právě tyto společné zájmy představují základ pro konstruktivní spolupráci partnerů.

WTO je instituce, která funguje na konsensuálním principu. Oproti jednáním na bilaterální úrovni se zde vzájemné vztahy Austrálie a EU v rámci této organizace uskutečňují na základě principu rovnoprávnosti. S ohledem na vliv EU jako obchodní velmoci otevírá pro Austrálii úzká a konstruktivní spolupráce s Unií příležitost ke zvětšení svého vlivu na mnohostranný obchodní systém. ${ }^{22}$ Sektor zemědělství však bude i nadále představovat rozporuplný aspekt vzájemných vztahů na půdě WTO a zůstane i nadále zdrojem neshod mezi partnery zejména po neúspěchu dosáhnout dohody při rozhovorech v Ženevě v červenci $2006 .{ }^{23}$

\section{Literatura}

[1] A stopped clock ticks again. Economist, 2005, roč. 377, č. 8448, s. 76-79.

[2] Agricultural Policie in OECD Countries: At a Glance. 2006 Edition, Paris, OECD Publications, 2006.

[3] CIHELKOVÁ, E.: Vnější ekonomické vztahy Evropské unie. 1. vyd., Praha, C. H. Beck, 2003.

[4] Der Ärger über das Aussetzen der Doha-Runde wächst. Frankfurter Allgemeine Zeitung, 23. 09. 2006, s. 14.

[5] Industrie- und Entwicklungsländer wollen neue WTO-Runde. Die Welt. 11. 09. 2006 (http://www.welt.de/data/2006/09/11/1032225.html).

[6] International Trade Statistics 2006. WTO. (http://www.wto.org/english/res_e/statis_e/its2006_e/its06_toc_pdf_links_e.htm).

[7] KENYON, D. and KUNKEL, J.: Australia and the European Union in the World Trade Organisation: partners or adversaries? Australian Journal of International Affairs, 2005 , roč. 59, č. 1, s. 55-69.

[8] KUNKEL, J.: Australian trade policy in an age of globalisation. Australian Journal of International Affairs, 2002, roč. 56, č. 2, s. 237-251.

[9] Němec, P.: Varování z Hanoje. Ekonom, 2006, č. 47, s. 23.

22 Kenyon, cit. 4, s. 68.

23 Jednáním zahájeným před pěti lety v katarském Dauhá tak nyní hrozí úplný kolaps či odložení o několik let. Rozhovory zaměřené na omezování tarifních překážek obchodu a zemědělských subvencí ztroskotaly v červenci 2006 poté, co se nepodařilo najít shodu nad otázky ohledně způsobu omezování tarifních překážek a dotací farmářům. Dosažení dohody do jara přištího roku je významné zejména z hlediska časově omezeného mandátu , tzv. Trade Promotion Autority neboli fast track, Bushovy administrativy, který, nebude-li prodloužen, vyprši $\mathrm{v}$ červenci. 
[10] Special Report: The WTO under fire - The Doha round; The Doha round. Economist, 2003, roč. 368 , č. 8342 , s. 30.

[11] SWINBANK, A.: Developments in the Doha Round and WTO dispute settlement: some implications for EU agricultural policy. European Review of Agricultural Economics, 2005, roč. 32, č. 4, s. 551-561.

[12] ŠTĚRBOVÁ, L.: Světová obchodní organizace: co se vlastně děje. Britské listy, 27. 07. 2006, http://www.blisty.cz/2006/7/28/art29539.html (03. 12. 2006).

[13] Talking the talk. Economist, 2004, roč. 372, č. 8384, s. 14.

[14] Vintage farm war lingers. The Australian, 10. 03. 2000, s. I08.

[15] WTO to press for resumption of Doha. Journal of Commerce. 17. 10. 2006, s.1.

es.europa.int

www.dfat.gov.au/trade/

www.ecdel.org.au

www.euractiv.cz

www.ihned.cz

www.iht.com

www.mpo.cz

www.oecd.org

www.trademinister.gov.au

www.welt.de

www.wto.org 


\section{Př́lohy}

Tab. č. 1: Hlavní obchodní partneři EU v roce 2005

\begin{tabular}{|c|c|c|c|c|c|c|c|c|c|c|c|}
\hline \multicolumn{4}{|c|}{ Hlavní partneři na straně importu } & \multicolumn{4}{|c|}{ Hlavní partneři na straně exportu } & \multicolumn{4}{|c|}{ Hlavní obchodní partneři } \\
\hline & Partneři & Mil. eur & $\%$ & & Partneři & Mil. eur & $\%$ & & Partneři & Mil. eur & $\%$ \\
\hline & Svět & 1176055 & 100,0 & & Svět & 1061836 & 100,0 & & Svět & 2237891 & 100,0 \\
\hline 1 & USA & 163057 & 13,9 & 1 & USA & 251657 & 23,7 & 1 & USA & 414714 & 18,5 \\
\hline 2 & Č́na & 158098 & 13,4 & 2 & Švýcarsko & 81980 & 7,7 & 2 & Č́na & 209894 & 9,4 \\
\hline 3 & $\begin{array}{l}\text { Ruská } \\
\text { federace }\end{array}$ & 106766 & 9,1 & 3 & $\begin{array}{l}\text { Ruská } \\
\text { federace }\end{array}$ & 56445 & 5,3 & 3 & $\begin{array}{l}\text { Ruská } \\
\text { federace }\end{array}$ & 163211 & 7,3 \\
\hline 4 & Japonsko & 73243 & 6,2 & 4 & Čína & 51796 & 4,9 & 4 & Švýcarsko & 148334 & 6,6 \\
\hline 5 & Norsko & 67474 & 5,7 & 5 & Japonsko & 43663 & 4,1 & 5 & Japonsko & 116906 & 5,2 \\
\hline 6 & Švýcarsko & 66354 & 5,6 & 6 & Turecko & 41849 & 3,9 & 6 & Norsko & 101261 & 4,5 \\
\hline 7 & Turecko & 33492 & 2,8 & 7 & Norsko & 33787 & 3,2 & 7 & Turecko & 75341 & 3,4 \\
\hline 8 & Jižní Korea & 33326 & 2,8 & 8 & $\begin{array}{l}\text { Spojené } \\
\text { arabské } \\
\text { emiráty }\end{array}$ & 25288 & 2,4 & 8 & Jižní Korea & 53456 & 2,4 \\
\hline 9 & Tchaj-wan & 23835 & 2,0 & 9 & Kanada & 23681 & 2,2 & 9 & Kanada & 40855 & 1,8 \\
\hline 10 & Brazílie & 23300 & 2,0 & 10 & Rumunsko & 21825 & 2,1 & 10 & Indie & 40021 & 1,8 \\
\hline 11 & $\begin{array}{l}\text { Saúdská } \\
\text { Arábie }\end{array}$ & 22092 & 1,9 & 11 & Indie & 21110 & 2,0 & 11 & Brazílie & 39287 & 1,8 \\
\hline 12 & Alžírsko & 20735 & 1,8 & 12 & Austrálie & 20710 & 2,0 & 12 & $\begin{array}{l}\text { Saúdská } \\
\text { Arábie }\end{array}$ & 37535 & 1,7 \\
\hline 13 & Libye & 19473 & 1,7 & 13 & Hongkong & 20434 & 1,9 & 13 & Rumunsko & 37130 & 1,7 \\
\hline 14 & Indie & 18911 & 1,6 & 14 & Jižní Korea & 20130 & 1,9 & 14 & Tchaj-wan & 36653 & 1,6 \\
\hline 15 & Singapur & 18219 & 1,5 & 15 & JAR & 18077 & 1,7 & 15 & Singapur & 35447 & 1,6 \\
\hline 27 & Austrálie & 9472 & 0,8 & & & & & 20 & Austrálie & 30182 & 1,3 \\
\hline
\end{tabular}

Pramen: Australia. General Statistics. http://trade.ec.europa.eu/doclib/docs/2006/september/tradoc_113346.pdf, s. 5. 
Tab. č. 2: Hlavní obchodní partneři Austrálie v roce 2005

\begin{tabular}{|c|c|c|c|c|c|c|c|c|c|c|c|}
\hline \multicolumn{4}{|c|}{ Hlavní partneři na straně importu } & \multicolumn{4}{|c|}{ Hlavní partneři na straně exportu } & \multicolumn{4}{|c|}{ Hlavní obchodní partneři } \\
\hline & Partneři & Mil. eur & $\%$ & & Partneři & Mil. eur & $\%$ & & Partneři & Mil. eur & $\%$ \\
\hline & Svět & 102835 & 100,0 & & Svět & 81071 & 100,0 & & Svět & 183906 & 100,0 \\
\hline 1 & $E U$ & 24387 & 23,7 & 1 & Japonsko & 17125 & 21,1 & 1 & $E U$ & 33415 & 18,2 \\
\hline 2 & USA & 14633 & 14,2 & 2 & Č́na & 9706 & 12,0 & 2 & Japonsko & 28680 & 15,6 \\
\hline 3 & Čína & 14404 & 14,0 & 3 & $E U$ & 9028 & 11,136 & 3 & Čína & 24110 & 13,1 \\
\hline 4 & Japonsko & 11555 & 11,2 & 4 & Jižní Korea & 6633 & 8,2 & 4 & USA & 20302 & 11,0 \\
\hline 5 & Singapur & 5922 & 5,8 & 5 & USA & 5669 & 7,0 & 5 & Jižní Korea & 10133 & 5,5 \\
\hline 6 & Malajsie & 4126 & 4,0 & 6 & Nový Zéland & 5483 & 6,8 & 6 & Nový Zéland & 9138 & 5,0 \\
\hline 7 & Nový Zéland & 3655 & 3,6 & 7 & Indie & 4233 & 5,2 & 7 & Singapur & 8369 & 4,6 \\
\hline 8 & Jižní Korea & 3501 & 3,4 & 8 & Thajsko & 2527 & 3,1 & 8 & Thajsko & 5768 & 3,1 \\
\hline 9 & Thajsko & 3240 & 3,2 & 9 & Singapur & 2446 & 3,0 & 9 & Malajsie & 5665 & 3,1 \\
\hline 10 & Indonésie & 2490 & 2,4 & 10 & Indonésie & 2216 & 2,7 & 10 & Indie & 5054 & 2,7 \\
\hline 11 & Vietnam & 2293 & 2,2 & 11 & Hongkong & 1646 & 2,0 & 11 & Indonésie & 4706 & 2,6 \\
\hline 12 & $\begin{array}{l}\text { Papua-Nová } \\
\text { Guinea }\end{array}$ & 1332 & 1,3 & 12 & Malajsie & 1539 & 1,9 & 12 & Vietnam & 3702 & 2,0 \\
\hline 13 & Kanada & 1260 & 1,2 & 13 & JAR & 1153 & 1,4 & 13 & Hongkong & 2543 & 1,4 \\
\hline 14 & JAR & 1033 & 1,0 & 14 & Kanada & 1100 & 1,4 & 14 & Kanada & 2360 & 1,3 \\
\hline 15 & Švýcarsko & 1013 & 1,0 & 15 & $\begin{array}{l}\text { Saúdská } \\
\text { Arábie }\end{array}$ & 1064 & 1,3 & 15 & JAR & 2186 & 1,2 \\
\hline
\end{tabular}

Pramen: Australia. General Statistics. http://trade.ec.europa.eu/doclib/docs/2006/september/tradoc_113346.pdf, s. 6.

\section{Graf č. 1: Struktura exportů ve fiskálním roce $2005 / 2006$}

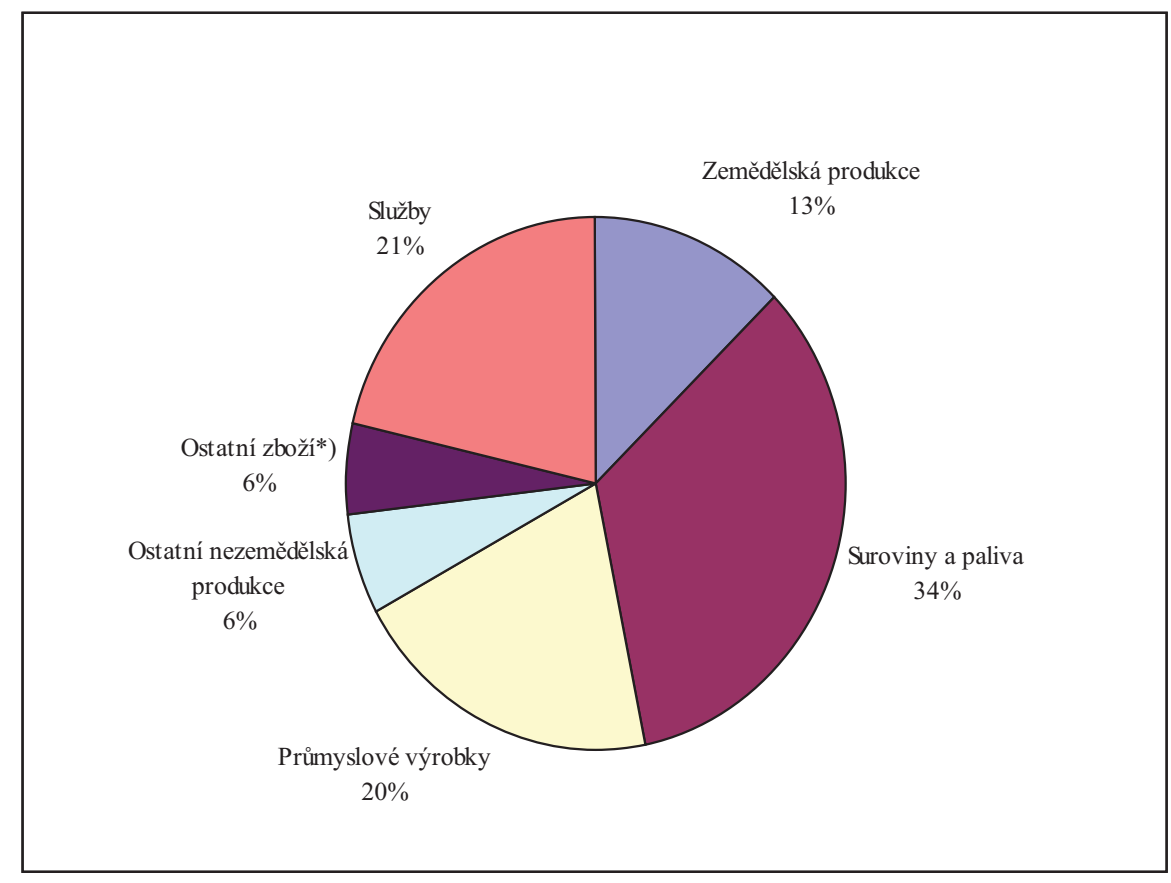

*) Zahrnuje zboží pro zpracování, opravy, zboží obstarané přepravci a nemonetární zlato.

Pramen: Trade Topics. A Quaterly Review of Australia's International Trade. Summer 2006. http://www.dfat.gov.au/publications/stats-pubs/trade_topics_sepqtr06.pdf, s. 24. 
Tab. č. 3: Export australské zemědělské produkce podle zemí v roce 2005 (s výjimkou rybolovu, lesnictví a kaučuku)

\begin{tabular}{|c|l|c|c|}
\hline & \multicolumn{1}{|c|}{ Partnerská země } & Hodnota exportů v tisících AUD & $\%$ \\
\hline & Všechny země & 26343030 & 100,0 \\
\hline 1 & Japonsko & 4882321 & 18,5 \\
\hline 3 & USA & 3013878 & 11,4 \\
\hline 4 & Č́́na & 2253653 & 8,6 \\
\hline 5 & Jelká Bríń Korea & 1225186 & 4,7 \\
\hline 6 & Nový Zéland & 1088866 & 4,1 \\
\hline 7 & Indonésie & 1002527 & 3,8 \\
\hline 8 & Tchaj-wan & 851099 & 3,2 \\
\hline 9 & Malajsie & 626408 & 2,4 \\
\hline 10 & Singapur & 509066 & 1,9 \\
\hline 11 & Saúdská Arábie & 507085 & 1,9 \\
\hline 12 & Thajsko & 447293 & 1,7 \\
\hline 13 & Itálie & 405073 & 1,5 \\
\hline 14 & Kanada & 396334 & 1,5 \\
\hline \hline
\end{tabular}

Pramen: http://www.dfat.gov.au/trade/negotiations/trade_in_agriculture.html 